\title{
Migrants, migration policies, and international business research: Current trends and new directions
}

\author{
Helena Barnard ${ }^{1}$, \\ David Deeds ${ }^{2}$, Ram Mudambi ${ }^{3}$ \\ and Paul M. Vaaler ${ }^{4}$ \\ ${ }^{1}$ Gordon Institute of Business Science, University of \\ Pretoria, 26 Melville Road, Illovo, Johannesburg, \\ South Africa; ${ }^{2}$ Opus College of Business, University \\ of St. Thomas, 1000 LaSalle Avenue South, \\ Minneapolis, MN 55403, USA; ${ }^{3}$ Fox School of \\ Business, Temple University, 548 Alter Hall, \\ Philadelphia, PA 19122, USA; ${ }^{4}$ Law School \& \\ Carlson School of Management, University of \\ Minnesota, 321 19th Avenue South, Minneapolis, \\ MN 55455, USA \\ Correspondence: \\ PM Vaaler, Law School \& Carlson School of \\ Management, University of Minnesota, 321 \\ 19th Avenue South, Minneapolis, MN 55455, \\ USA. \\ Tel: +1 612625 4951; \\ e-mail: vaal0001@umn.edu
}

The authors are listed alphabetically.

Online publication date: 8 November 2019

\begin{abstract}
Migrant and migration policy (MMP) issues have often influenced important international business (IB) research questions, but the last 20 years have seen the emergence of new or "renewed" MMP issues tied to changes in migrant demographics, wealth, skills, home-country provenance, host-country attitudes, and international governance. Articles in the inaugural special issue of the Journal of International Business Policy address those issues, connect them to classic IB research questions, and then develop theory and evidence to inform current IB scholarly debates and guide IB executives, investors, and the public policy-makers overseeing those business activities. Our introductory article provides an overview of new and renewed MMP issues addressed in the special issue. It defines foundational MMP concepts and trends, compares classic IB and current MMP research questions, summarizes the eight articles included in the special issue, and offers suggestions for advancing research in both fields.
\end{abstract}

Journal of International Business Policy (2019) 2, 275-288.

https://doi.org/ | 0.1057/s422 | 4-019-00045-6

Keywords: migrants; migration policy; multinational enterprises; foreign direct investment; remittances; entrepreneurship; knowledge flows; corporate social responsibility

\section{INTRODUCTION}

This article introduces the inaugural special issue of the Journal of International Business Policy (JIBP) on migrants, migration policies (MMPs) and international business (IB) research. We began our editorial work eighteen months ago convinced that IB executives and investors in the past two decades faced new MMP issues meriting a fresh look at theories, evidence, and practical insights that might better inform IB scholarly debates about migrants and guide IB executives and investors as well as public policy makers actually living those debates. Eighteen months later, our conviction has changed only slightly. The articles included in the special issue contribute IB-grounded theories, evidence and practical insight on both new and "renewed" MMP issues.

To be sure, we identified genuinely new MMP issues for study from an IB perspective. The past twenty years saw the emergence of a new kind of organization dedicated specifically to serving migrant communities abroad and coordinating their activities in support of 
economic, political, and social development back home. The policy scope of, say, Zambia's Diaspora Liaison Office includes a mix of foreign affairs, economic development, human rights, worker training, voting information dissemination, even family services. The emergence of these "diaspora engagement institutions" (Gamlen et al., 2019) means new host-country government stakeholders for IB executives to consider when evaluating investment projects affecting the livelihoods of host-country citizens at home and abroad.

We also identified IB research opportunities to study MMP issues figuring importantly in current debates but also in similar debates from other eras. In many countries of the developed North, public policies and related social attitudes toward migrants and migration took decidedly negative turns in the 2010s. A US presidential candidate won office promising to build a wall on the southern border with Mexico (New York Times, 2019). A UK politician positioned himself to become prime minister by advocating a "Brexit" from the European Union to stop "uncontrolled" migration (Johnson, 2016). On the hustings, their policy proposals cater to populist fears of poor, uneducated, crime-prone migrants from the developing South flooding across borders of countries in the developed North. In office, their enacted policies complicate efforts by firms from the developed North to attract individuals from a relatively small pool of highly-skilled scientists, engineers, and information technologists in the developing South (Lewin, Massini \& Peeters, 2009). They complicate knowledge management strategies at multinational enterprises (MNEs) dependent on the easy movement of executives from one national subsidiary operation to another (Williams, 2007). They complicate the process of attracting would-be migrant entrepreneurs keen to found new businesses, commercialize new technologies, and build new industries abroad (Schuler, Jackson \& Tarique, 2011).

These negative turns in public policies and social attitudes would have been familiar to IB executives recruiting foreign-born technical specialists, transferring executives abroad, or looking for entrepreneurs overseas a century earlier. During another era of rising xenophobia, another US president enacted an Immigration Limitation Act of 1917 imposing English literacy tests on would-be migrants (Tichenor, 2002). Another UK prime minister oversaw passage of an Aliens Order Act of 1920 severely limiting employment rights of alien residents (Bashford \& McAdams, 2014). When IB researchers investigate current public policies and social attitudes toward migrants in home and host countries, they may very well be uncovering a close variant of past policies and attitudes. History often rhymes if it does not repeat itself.

Whether new or renewed, MMP issues create commercial opportunities and dangers for IB executives and investors, some with broader economywide implications important to policy makers. Lorenzen and Mudambi (2013) describe an MMPrelated opportunity. Indian migrant networks linking Mumbai and Los Angeles in the 2010s have provided Bollywood studio executives and investors an opportunity to "catch up" with Hollywood by observing and transferring best industry practices back to India and marketing successful Indian movies to the US. Chami, Ekkehard, Fullenkamp, and Oeking (2018) describe an MMP-related danger. In the 2010s, Lebanese migrant networks around the world have remitted hundreds of millions of dollars annually to extended family members back home. Wealthier family members in Beirut may represent a commercial opportunity for a local retailer, but a remittance "trap" stifles broader economic growth for the country. Those same family members are less motivated to enter the domestic workforce, create new businesses, and contribute to private-sector, small-business, entrepreneur-led economic growth prescribed by most development academics (e.g., Ács \& Szerb, 2007) and professionals (e.g., Booth, Calabrese, \& Golooba-Mutebi, 2018).

The articles we curated for the special issue address these and other new or renewed MMP issues confronting IB executives and investors. They analyze IB research and practice implications of: a dramatic rise in the value of migrant remittances to and the number of migrant ministries in many developing countries (Cummings \& Gamlen, 2019); an escalating battle for skilled migrants only a few developing countries are producing but many developed-country MNEs need (Chand \& Tung, 2019; Emmanuel, Elo, \& Piekkari, 2019); a change in the mix of migrants "pulled" to host countries by economic opportunity versus migrants "pushed" from home countries by conflict, violence, and persecution (Christensen, Newman, Herrick \& Godfrey, 2019); a debate about how migrants influence the direction of FDI from their host countries (Kunczer, Lindner \& Puck, 2019); a shift in home-country citizen attitudes that now treat migrants living abroad as role models rather than renegades (Kautto, 2019); a trend among MNEs 
operating in "fragile states" to hire and train refugees as hedges against political risks and demonstrations of corporate social responsibility (CSR) (Reade, Oetzel, \& McKenna, 2019); and a growth in public-private partnerships between government-run investment development agencies offering financial incentives to attract inward FDI and non-governmental migrant community organizations able to identify firms abroad more likely to respond to those incentives (Poliakova, Riddle, \& Cummings, 2019).

In each article, the authors develop theory to explain connections between these MMP issues and IB executive and investor responses. They also document those connections, sometimes with illustrative anecdotes, sometimes with detailed case studies, sometimes with broad-sample statistical studies. In the process, the authors contribute new and novel insights on classic IB research questions. Why do MNEs emerge in some countries but not in others? It is, perhaps, the oldest question in our field with "modern" answers dating back to Stephen Hymer's dissertation research (1970/1960). In the special issue, Reade, Oetzel, and McKenna (2019) explain why MNEs emerge and recruit migrant refugees in countries prone to political violence. Why do entrepreneurs go abroad to establish new ventures that force them to carry liabilities of both "newness" and "foreignness" so often fatal to those ventures? Depending on how you read history, this IB question is $25-30$ years old (Murrow, 1988; Oviatt \& McDougall, 1994). In the special issue, Cummings and Gamlen (2019) answer an inverted version of that question. They explain why migrants living abroad have advantages in funding and founding new ventures back home. In each article of the special issue, you will see how MMP concepts help answer classic IB research questions in new and novel ways.

To elaborate on these points and others, we have organized the remainder of this introductory article into four additional sections. In the next section, we lay a foundation for our review by defining and discussing selected MMP terms and trends. In the third section, we pose several classic IB research questions and show how MMP players matter in answering them. We also pose several current MMP research questions and demonstrate their close connection to IB studies. In the fourth section, we summarize the eight articles included in the special issue. In the final section, we conclude with observations about how to build on the special issue articles and advance research on MMP issues from an IB perspective.

\section{FOUNDATIONAL TERMS AND TRENDS}

Terms like "migrant" and "diaspora" and "transnational" recur across articles in the special issue. Discussion of such terms lays a helpful foundation for special issue readers, especially those less familiar with MMP issues outside the IB research domain. At first glance, it may seem like IB scholars have been latecomers to the study of MMP issues compared to scholars in sociology, economics, and international relations. While we think that first glance misleading, our discussion of foundational terms and trends will rely more on authorities outside rather than inside the IB field. More specifically, we ground out discussion primarily in work by Beine, Docquier \& Özden (2011) from development economics, Portes et al. (2002) from sociology, Cohen (2008) from migration studies, and Vaaler (2011) from IB.

A simple definition of an international "migrant" is anyone living outside the country of their birth or youth (Vaaler, 2011). It is simple but also restrictive. It defines migrants solely by their birth certificate or primary educational diploma rather than other dimensions of identity such as legal citizenship, de facto residence, or identity based on shared values with and/or sentiments for the homeland. Cohen (2008) describes the Irish diaspora as migrants and their descendants, which number multiples of the country's population of about five million at the end of 2018. In the special issue, Poliakova, Riddle, and Cummings (2019) narrate the story of promoting migrant-based FDI to Ireland by appealing to first-generation Irish business executives living abroad. A natural extension of their case study would investigate the effectiveness of similar FDI promotions for overseas business executives lacking an Irish birth certificate or school diploma, but still attracted by deeper ancestral links to the Emerald Isle.

Even using our simpler, more restrictive definition of migrant, their numbers compel our attention. At the end of 2018, there were more than 250 million individuals living outside their country of birth or youth. That is up 80 million from 2000 and almost 170 million from 1970 (IOM, 2018). As Christensen, Newman, Herrick, and Godfrey (2019) explain, many leave home seeking better economic opportunities. Some leave home involuntarily because of threatened conflict, violence, and/or 
persecution. Some leave with every intention to return after seasonal work abroad concludes or after threats pass. Others leave to start a new life abroad in permanence. As we will learn below, differences in motivation and expected tenure matter for how migrants choose a living in the host country, including whether they choose to create their own living abroad as an entrepreneur.

Today, this virtual country of "Diasporia" is the fifth largest in the world. In the past 200 years, these migrants varied from 2-5 percent of the world population with Diasporia comprising 3.3 percent of the world population at the end of 2018. The same percentage was only 2.2 (84 million) in 1970 . From 1910-1990, migrant percentages were in the lower part of the 3-5 percent range. Two world wars, a cold war, and a Great Depression created international mobility barriers for people as well as trade and investment. Since 1990, migrant percentages of world population have been reverting to higher historical trends.

According to Beine et al. (2011) the Greek etymology of "diaspora" comes from agriculture. It is a "scattering" or "sowing of seeds" invoking notions of dispersion and growth. In modern usage, it refers to people defined by common language, ethnicity, religion, or nationality but not living where those common traits are native. Whether by choice or by force, these people leave the homeland, settle abroad, and develop a collective sense of cultural identity abroad, usually as a minority. Economically, a diaspora typically refers to migrants living in a particular "host" (or "destination" or "receiving") country and their collective impact on common indicators of economic development such as growth or poverty alleviation. In the mid-twentieth century, notable permanent diasporas included the Turkish Gastarbeiter in Germany (Rudolph, 2010), while notable diasporas regularly forming and then disbanding with the seasons included Mexican Braceros working farmlands in the US Southwest (Clemens, Lewis \& Postel, 2018). In the early twenty-first century, notable diasporas include Somalis living in the "Little Mogadishu" district of Nairobi, Kenya (Daily Nation, 2019), and South Asians building sports stadiums while living in designated areas outside Doha eerily reminiscent of segregated townships in Apartheid-era South Africa (Reuters, 2016). In the longer arc of history, notable diasporas include Armenians, Chinese, Jews, and Lebanese scattered throughout the world for decades, centuries, even millennia (Cohen, 2008).
Thanks to recent programs funded by the World Bank and United Nations, we now have better information about recent diaspora demography and migration trends (Docquier \& Marfouk, 2006; Docquier \& Rapaport, 2012; Özden, Parsons, Schiff \& Walmsley, 2011). Some recent trends fit intuition. Since men tend to be the first to migrate, they account for slightly more than half of most diasporas, especially when more recently formed. Diaspora members are better educated than their counterparts back home. In the 2000s, from fifteen to twenty percent of Jamaican adults had some tertiary (university) education, but among adults in the Jamaican diaspora largely located in the US and UK, more than eighty percent have some tertiary education (Docquier \& Marfouk, 2006). Such educational disparities support "brain drain" claims by many home countries in the developing world and suggest that countries of the developed North have been effective in attracting skilled migrants. This may follow from host-country immigration policies Chand and Tung (2019) analyze in the special issue, from other non-policy factors in the host country, or most likely from some mix of both.

Since the 2000s, however, at least two trends challenge intuition. One trend is an increasing rate of "South-South" migration between developing countries, particularly in Africa. This trend also applies to diasporas comprised of better-educated migrants. One reason for that geographic shift in migration patterns is an upsurge in conflict, violence, and persecution in the developing South. 2018 alone saw almost three million new refugees crossing borders (UNHCR, 2019). Migrants forced out of home countries by sudden threats move more quickly but less distantly than migrants leaving home to find better economic opportunities.

Another trend challenging intuition is an increase in migrant remittances. The size of Diasporia increased by about a third after 2000 . That increase came more in the developing South than the developed North. Since 2000, the dollar value of migrant money sent home in small-sum, individual-to-individual or household-to-household transfers increased six-fold. Remittances shot up from $\$ 100$ billion in 2000 to $\$ 600$ billion in 2018 with about $\$ 500$ billion going to low and middleincome developing countries (World Bank, 2019).

Putting these developments together leads to several conjectures worth closer study: migrants are becoming wealthier faster; migrants are able to do so in other developing countries where 
conventional labor market opportunities are scarce and entrepreneurial self-employment more prevalent; and migrants are sharing more of that wealth with home-country families and local communities. These recent developments and conjectures help explain recent studies documenting, for example, robust links between migrant remittances to and more venture investment activity in many lessdeveloped countries (e.g. Martinez, Cummings \& Vaaler, 2015).

In addition to migrant and diaspora, the term "transnational" also features importantly in the special issue. More than 30 years of research in sociology by Portes and others (e.g. Portes et al., 2002) helped define and apply the transnational concept to individual migrant and collective diaspora phenomena. Individual migrants straddle home and host countries. Their behavior follows from a dual identity informed by both social contexts. Thus, they can more easily move between both and take advantage of arbitrage opportunities than native-born residents in either country.

In practice, migrant transnationality means new business founding, broader industry growth and even broader economic development. Saxenian (2005) tells stories about migrants shuttling back and forth between home countries like India or Greater China and host countries like the US and Canada where they run high-tech ventures. Overseas Chinese invested back home and created an electronics industry cluster in Hsinchu, Taiwan (Saxenian \& Hsu, 2001). Overseas Indians invested back home and created a software industry cluster in Bangalore (Lorenzen \& Mudambi, 2013). These stories refute claims of a brain drain from the developing South. Migration more often sets in motion a process of brain "circulation" with knowledge and innovation as well as people and money coursing between home and host countries (Schotter, Mudambi, Doz \& Gaur, 2017).

More concentrated diasporas facilitate that circulation and make discovery in both countries more likely. When migrants live more closely together they can build institutions with public good characteristics: community banks specializing in remittances to migrant home countries; community schools instructing migrants and their immediate family members in languages and histories of host and home countries; community newspapers and other media keeping migrants informed of homecountry politics and policies affecting general migrant livelihood; community centers where migrants might learn about more specific opportunities to lend to and invest in businesses back home. Along with these other foundational MMP terms and trends, the transnational concept helps us understand why migrants often figure so importantly in IB research questions, including those we next discuss.

\section{CLASSIC IB AND CURRENT MMP RESEARCH QUESTIONS}

Migrants and migration have played implicit and sometimes explicit roles in helping to answer many classic IB research questions, including those pictured in Table 1. Hymer (1970 (1960)) provided the first modern IB research answer to the question of MNE emergence. They emerged when technological advantages permitted the establishment of "monopolizing" international exchange relationships between national subsidiaries. Buckley and Casson's (1976) "internalization theory" of the MNE built on Hymer's logic. Technology advantages might prompt the internalization of several production steps within an MNE. The administrative challenge would then be to move goods and services from one to another national subsidiary based on some mix of internal transfer rules and prices set by the MNE headquarters. These theories and others (e.g. Teece, 1986) helped explain why MNEs emerged and accounted for so much international exchange between countries of the developed North.

Table 1 Classic IB research questions and articles

\begin{tabular}{|c|c|c|c|c|}
\hline $\begin{array}{l}\text { Why do MNEs } \\
\text { emerge? }\end{array}$ & $\begin{array}{l}\text { How are MNEs } \\
\text { organized and } \\
\text { controlled? }\end{array}$ & $\begin{array}{l}\text { How do MNEs transfer } \\
\text { knowledge internationally? }\end{array}$ & $\begin{array}{l}\text { How do MNEs choose FDI } \\
\text { locations, and modes? }\end{array}$ & $\begin{array}{l}\text { How do international new } \\
\text { ventures emerge? }\end{array}$ \\
\hline Hymer (1970) & Kolde and Hill (1967) & Teece, (1977) & Dunning (1977) & Murrow (1988) \\
\hline $\begin{array}{l}\text { Buckley and } \\
\text { Casson } \\
(1976)\end{array}$ & $\begin{array}{l}\text { Bartlett and Ghoshal } \\
\text { (1989) }\end{array}$ & Kogut and Zander (1993) & Kogut and Singh (1988) & $\begin{array}{l}\text { Oviatt and McDougall } \\
\text { (1994) }\end{array}$ \\
\hline
\end{tabular}


In an earlier age, however, MNE theories followed a different azimuth sometimes involving migrants. As Teece (1986) notes, some of the earliest MNEs were international trading, extractive industry, or agricultural firms moving raw materials from the developing South to the developed North. These "arbitrage" theories of the nineteenth and early twentieth centuries explained the emergence of MNEs with migrants in leading roles. In hostcountry colonies migrants extracted, harvested, or grew the raw materials for transport to home countries where they were manufactured and then sold back to migrant colonials at a premium. Lenin (1999 (1916)) thought this circular process central to a final "imperial" phase of capitalism in the West.

Migrants and migration policies figured prominently in answers to other classic IB research questions, including how MNEs are organized and controlled. More than 50 years ago, Kolde and Hill (1967) highlighted the important corporate control role expatriate executives play in many international firms. These corporate migrants typically shared a common language and cultural understanding to interpret broader corporate goals set from afar. 30 years ago, Bartlett and Ghoshal (1989) analyzed the competitive advantages of "transnational" MNEs organized and managed to take advantage of both efficiencies permitted by centralized production and responsiveness permitted by decentralized marketing and sales activities. Corporate migrants moved easily between national subsidiaries to coordinate their activities and then share their experience with others as part of a continuous learning process in transnational MNEs. Corporate migrants are the central agents of effective MNE transnationality.

The centrality of migrant executives in MNE organization and control roles leads naturally to important roles in the transfer of knowledge across MNE operations (Kogut \& Zander, 1993; Teece, 1977). It leads to important roles in managing the FDI process under different modes such as a wholly owned subsidiary or a joint venture (Dunning,
1977; Kogut \& Singh, 1988). The rise of international entrepreneurship studies in the late 1980s (Murrow, 1988) and 1990s (Oviatt \& McDougall, 1994) meant greater interest in the transnational characteristics of migrants often funding, founding, and actively managing those new ventures. The ability to straddle home and host countries permitted faster venture emergence and let international entrepreneurs survive and succeed in those ventures even as they carried burdens of newness and foreignness.

Current MMP research addresses questions that parallel the classic IB research questions. Look at Table 2 listing a few of those MMP research issues in question form. Why do diasporas emerge? As Cohen (2008) notes, two prominent explanations feature IB factors placed in different causal sequence. We can illustrate this with examples from antiquity. More than 3500 years ago, Phoenician merchants fanned out from what is now Lebanon to establish trading and manufacturing settlements across the Mediterranean. Follow-on migration from Tyre and Sidon to Cyrene, Carthage, Sicily, Sardinia, and Tangiers laid foundations for a Carthaginian Empire rivaling Rome in the third century BCE (Aubet, 2013). IB opportunity led to migration and diaspora formation. Then again, forced migrations of ancient Hebrews starting with the Babylonian conquest and exile of the fifth century BCE spread Jews across the West eventually permitting the development of extended family networks offering international trade and financial assistance (Johnson, 1987). In this case, migration led to IB activities in dispersed extended family networks.

However started, diaspora development often includes these elements discussed by Beine et al. (2011): geographic concentration in community enclaves; the creation of organizations with public good characteristics; public, private, and civil society institutions providing local diaspora governance; more recently, home-country government agencies facilitating travel to and communication with home countries, and participation in home-

Table 2 Current MMP research questions and articles

\begin{tabular}{lllll}
\hline $\begin{array}{l}\text { Why do migrant } \\
\begin{array}{l}\text { communities (Diasporas) } \\
\text { emerge? }\end{array}\end{array}$ & $\begin{array}{l}\text { How are } \\
\text { diasporas } \\
\text { governed? }\end{array}$ & $\begin{array}{l}\text { How does diaspora } \\
\text { knowledge flow } \\
\text { internationally? }\end{array}$ & $\begin{array}{l}\text { How do migrants choose/ } \\
\text { influence FDI locations? }\end{array}$ & $\begin{array}{l}\text { How do migrant new } \\
\text { ventures emerge? }\end{array}$ \\
\hline $\begin{array}{l}\text { Cohen (2008) } \\
\begin{array}{l}\text { Beine, Docquier, and Özden } \\
(2011)\end{array}\end{array}$ & $\begin{array}{l}\text { Meyer (2010) } \\
\text { Gamlen (2019) }\end{array}$ & $\begin{array}{l}\text { Madhaven and Iriyama } \\
(2009)\end{array}$ & $\begin{array}{l}\text { Leblang (2010) } \\
\text { Barnard and Pendock (2013) }\end{array}$ & $\begin{array}{l}\text { Shukla and Cantwell (2018) } \\
\text { Wright (2009) } \\
\text { Hernandez (2014) }\end{array}$ \\
\hline
\end{tabular}


country civic activities (e.g., voting). Vaaler (2013) finds that remittances from migrants living in more geographically concentrated diasporas increase home-country venture funding and founding rates more than remittances from migrants living in more dispersed diasporas. When more migrants are present, the elements of diaspora development discussed by Beine et al. help identify and exploit new venture opportunities back home.

How are diasporas governed? This question has drawn increasing interest among migration studies scholars and policy advisors in the 2000s. Of course, governance in the context of diasporas has a different meaning compared to corporate contexts where formal employment and contracting relationships give senior executives and board members substantial say over employee activities. With diasporas, governance has a looser meaning related to how standards, conventions, customs are developed and observed nationally or internationally. With this in mind, Gamlen (2019) provides a thorough explanation for how diasporas are governed nationally through diaspora engagement institutions like the Zambia Diaspora Liason Office, regionally through bilateral and multilateral agreements protecting migrant rights in areas such as employment and housing, and globally through international institutions like the UN's International Organization on Migration. Among the special issue articles, Reade et al. (2019) draw an IB connection to these developments in migrant governance. They explain greater MNE interest in employing refugees as a CSR response to emerging international (UN) standards for the treatment of refugees. Such actions indicate progress in the development of what Meyer (2010) calls a "world society" where individual, corporate, and governmental actors adhere to loose but still discernible standards of care in the treatment of migrants around the world.

Answers to other current MMP research questions parallel classic IB research questions. Common family and home-country community connections, similar educational backgrounds, and, often, shared interests in the transnational exploitation of knowledge help explain how and why diasporas act as "carrier waves" of innovation to South Asia (Madhavan \& Iriyama, 2009) and Sub-Saharan Africa (Barnard \& Pendock, 2013). Their hostcountry political influence (Leblang, 2010) and "affinity" for the home country (Shukla \& Cantwell, 2018) provide answers to questions about how migrants influence outward FDI directions in host countries.

Drori, Honig, and Wright (2009) answer questions about how migrants affect international new venture emergence processes with analyses of different migrant entrepreneurship profiles. There are "international" entrepreneurs who gain an initial market foothold abroad via migrant communities. Meouloud, Mudambi, and Hill (2019) describe some from Francophone Africa. They tend to internationalize via expansion first to metropolitan France. The former colonizer is home to affluent African diasporas. Their patronage enriches and legitimizes international entrepreneurs.

Sometimes those international entrepreneurs never stray beyond migrant communities. They can become "enclave" entrepreneurs co-specializing venture offerings to migrant communities in specific neighborhoods. Wilson and Portes (1980) describe some operating in the "Little Havana" district of Miami. Cuban migrant entrepreneurs offer products and services with little limited value outside the district. Transactional conventions, including the language of transactional negotiation, differ from those used outside the district. Cospecialization with the neighborhood differentiates the venture, but also limits its growth potential.

Shifts from international to enclave entrepreneur often indicate a deeper shift in the dual identity of migrants. Though always straddling home and host countries, the relative importance of each can change with tenure abroad. The migrant as international entrepreneur may rely more on homerather than host-country knowledge and connections for survival and success. The migrant as enclave entrepreneur almost certainly relies more on host-country (neighborhood) knowledge and connections. Cummings, Deeds, and Vaaler (2019) document remittance patterns consistent with this same migrant tenure dynamic. In a broader sense, migrant tenure changes home- and host-country networks supporting new international ventures (Hernandez, 2014).

\section{THE SPECIAL ISSUE ARTICLES}

How do the eight articles in the special issue contribute to our understanding of these classic IB and current MMP research questions? Table 3 provides a summary answer to that question. It groups special issue articles under headings that state in brief how we think they integrate IB and MMP 
Table 3 Special issue article contributions to IB and MMP research

\begin{tabular}{|c|c|c|c|c|}
\hline $\begin{array}{l}\text { Analyzing when MNEs } \\
\text { are more likely to emerge } \\
\text { and employ refugees } \\
\text { from "Fragile States" }\end{array}$ & $\begin{array}{l}\text { Analyzing the impact of } \\
\text { diaspora engagement } \\
\text { institutions on home- } \\
\text { country remittance use }\end{array}$ & $\begin{array}{l}\text { Analyzing public } \\
\text { policy and cultural } \\
\text { factors influencing } \\
\text { skilled migration } \\
\text { trends }\end{array}$ & $\begin{array}{l}\text { Analyzing the micro } \\
\text { processes of migrant- } \\
\text { influenced outward } \\
\text { and inward FDI }\end{array}$ & $\begin{array}{l}\text { Analyzing the impact of } \\
\text { individual migrant } \\
\text { characteristics on } \\
\text { entrepreneurship in home } \\
\text { and host countries }\end{array}$ \\
\hline $\begin{array}{l}\text { Reade, Oetzel and } \\
\text { McKenna (2019) }\end{array}$ & $\begin{array}{l}\text { Cummings and Gamlen } \\
\text { (2019) }\end{array}$ & $\begin{array}{l}\text { Chand and Tung } \\
\text { (2019) Emmanuel, } \\
\text { Elo and Piekkari } \\
\text { (2019) }\end{array}$ & $\begin{array}{l}\text { Kunczer, Lindner, } \\
\text { and Puck (2019) } \\
\text { Polikava, Riddle, } \\
\text { Cummings (2019) }\end{array}$ & $\begin{array}{l}\text { Christensen, Newman, } \\
\text { Herrick, and Godfrey (2019) } \\
\text { Kautto (2019) }\end{array}$ \\
\hline
\end{tabular}

research to contribute new and novel insights advancing both research streams.

The eighteen-month process leading up to those contributions started in June 2018 with a daylong symposium run at the University of St. Thomas in conjunction with the Academy of International Business annual meeting in Minneapolis, Minnesota. From there, a call for proposals followed by submission of full manuscripts and then submission of revised manuscripts over the next several months led to the eight articles included in the special issue. Six of those eight articles appear immediately after this introduction. Two others will appear in a future issue of JIBP.

In selecting these eight articles, we kept in mind three principles enunciated by the JIBP editorial leadership. First, we sought articles investigating IB executives, investors, and their firms, but then went further. We wanted articles also investigating societal implications of IB phenomena (Van Assche, 2018). Second and related, we sought articles about individuals other than the "usual suspects" like MNEs and their executives, outside the "usual places" like North America and Western Europe, and beyond the "usual deals" like FDI in plant, property, and equipment. We wanted articles rendering insight on how Barnard's (2019) "social actors" mattered in IB transactions, how MNE transactions in some of the least-developed countries of the world were completed differently, how small dollar-value international transactions in informal economies were structured. Third, we sought articles highlighting public policy, public policy makers, and the institutions through which they work. Following Clegg's (2019) suggestion, we looked for articles that could shed new light on how different IB actors responded to policies, and in some cases, influenced them to the benefit or detriment of surrounding communities.

The first article in the special issue by Cummings and Gamlen (2019) represents those three principles quite well. They ask after the effects of diaspora engagement institutions on venture investment in developing countries. They analyze the political positioning of these institutions. Some are stand-alone government ministries where the leader has cabinet-level status. They analyze the policy intent of these institutions. Some are designed to "tap" migrants economically. Others "embrace" migrants politically or simply "govern" their diasporas with some globally-recognized standards of care. They then ask whether the political positioning and/or policy intent of these diaspora engagement institutions change remitting patterns among migrants in the diaspora.

Broad sample, panel data analyses related to these institutions and remittance trends in more than 40 developing countries observed in the 2000s tell an interesting story. The highlight is that certain diaspora engagement institutions increase the impact of migrant remittances on venture founding rates back home. They magnify the positive venture founding effect of remittances when institutions are more highly placed politically -they are a stand-alone ministry rather than part of another, say, foreign or economic development ministry. These institutions also magnify the positive impact of remittances when they are located in the executive rather than legislative branch of home-country governments. The underlying theoretical driver for this dynamic is social. More highly positioned home-country institutions intended to help migrants abroad prompt a greater sense of reciprocal obligation among the migrants they serve. Migrants feel they "owe" more to the home country and discharge that social debt by remitting to make longer-term investments in the homeland rather than remitting to finance household consumption that can be fleeting. The topic is novel, the theory original, the empirical methods well executed, and the results provocative both for MMP and IB research. 
The second article by Emmanuel, Elo, and Piekkari (2019) focuses on a single developing country, Tanzania. The authors investigate social actors and processes affecting migration and IB implications flowing from migration. More specifically, they ask why so many medical doctors in Tanzania choose not to migrate. Their education and training fits the skilled migrant profile well. A systematic shortage of healthcare professionals, particularly in less populated rural areas of North America and Western Europe, makes them prime targets for hiring and transport to fill talent gaps in hospitals and clinics in those same regions.

Notwithstanding those attractions, Emmanuel et al. (2019) find that many medical doctors in Tanzania stay in place and do so out of the sense of "purpose" related to home-country need and personal characteristics. Non-economic, emotional, and life-philosophical considerations outweigh prospective economic benefits from migration. The authors marshal evidence indicating that these purpose-related sentiments correlate with selfassessments of their ability to meet family obligations, the intensity of their religious faith, and their determination to address healthcare disadvantages in home-country communities. Analyses by Emmanuel et al. demonstrate the importance of noneconomic considerations among skilled professionals thought by many to be most vulnerable to the allure of "economic" migration. Their study will remind many readers of tensions between economic and non-economic factors affecting the diffusion of innovations across communities (Rogers, 1962) and worker motivation (Ryan \& Deci, 2000).

The special issue article by Chand and Tung (2019) also investigates determinants of migration by skilled workers. In nearly every respect, it differs from the article by Emmanuel et al. (2019). Chand and Tung document the immigration policies of three advanced economies that have been particularly successful at attracting skilled migrants: Australia, Canada and the US. They help readers understand the common policy elements of a government program to draw from that small pool of skilled migrants. Those policy elements include migrant categories (e.g., refugees), demand factors (e.g., having an offer of employment), and supply factors (e.g., domestic scarcity) typically influencing immigration systems based on points (Australia, Canada) or qualitative assessment (US).

Their comparative study matters for IB executives. In the developed North (and the developed
Antipodes), immigration policy reforms of the past two decades reflect a broad shift from goals of refugee resettlement and family reunification to "merit-based" systems. Australia and Canada have gone further in making that shift compared to the US and many countries of Western Europe. But many of these laggard countries have governments elected on platforms mandating a shift to meritbased immigration. The intent of that shift in at least of one those countries, the US, is not just to decrease unskilled immigration. It is also to decrease immigration generally. The dual intent of US immigration reform may explain why so many US-based IB executives oppose current policy reforms proposed by President Trump (CNBC, 2019).

Two articles in the special issue investigate MNEs and IB executive decision-making in unusual contexts. Reade et al. (2019) ask why MNEs operating in countries prone to sudden economic dislocation and political violence might reach out and employ refugees affected by those threats. We should ask why those MNEs are in these fragile states in the first place. The answer is usually found in or on the ground: oil, gold, or rare earths in the ground; star fruit, palm oil plants, or teak wood on the ground. Once there, MNEs are usually interacting with hostcountry governments as part of the "evolving" bargain that is FDI in developing countries. For Reade et al., legitimacy with the host-country government and individuals in the surrounding community means a little less evolution and more favorable investment conditions.

MNE human resource management (HRM) strategies can affect the likelihood of change in investment conditions. In fragile states refugees can be highly skilled but unemployed. Here is where Reade et al. (2019) analyze different HRM strategies to understand which MNEs are more likely to employ refugees, perhaps to gain greater legitimacy with host-country stakeholders, perhaps to meet perceived social responsibilities to host-country communities, perhaps to do both.

At first glance, their analysis might seem more normative and prescriptive rather than analytical and descriptive. Take a second look. Their study features a quite searching analysis of different MNE HRM systems. Those with a stronger orientation toward local responsiveness rather than global efficiency are also more likely to employ refugees. MNE executives designing HRM systems will find novel insights to take back to their colleagues. MNEs ameliorate suffering when they provide 
employment to refugees in fragile states. They also alleviate some of the "push" factors that increase refugee numbers. Factors affecting the likelihood of hiring refugees go beyond nobler notions related to corporate social responsibility. They also include more mundane factors tied to MNE strategy and structure (Chandler, 1962). Reade et al. (2019) show us how in a fascinating context.

Another article in the special issue by Kunczer, Lindner, and Puck (2019) investigates the influence of migrants on MNE decisions about where to invest abroad. Since Leblang's (2010) path-breaking study of migrant influence on outward FDI, researchers in IB (e.g., Shukla \& Cantwell, 2018) and related fields have been investigating underlying mechanisms. Kunczer et al. think an important mechanism is information. Migrants can help MNEs reduce uncertainty associated with outward FDI in migrant home countries.

But how? The authors answer that question for MNEs in Austria. The analysis drills down from national to sub-national municipalities, and to even smaller districts where the authors can observe immigrant counts in the neighborhoods immediately surrounding MNEs. These are counts of immigrants in the neighborhood, but not necessarily in employed by the MNEs. Anchoring their analysis in the knowledge-based view (KBV) of the firm, Kunczer and colleagues show that more immigrants in the neighborhood from country " $x$ " increases the likelihood of MNE internationalization into the same country "x." Two factors diminish the strength of that relationship: (1) greater variability in home-country institutions, which might decrease the value of immigrant knowledge from a past period, and (2) greater host-country anti-immigrant sentiment, which might decrease interactions between MNE executives and local immigrants. This study pairs the KBV with FDI locational theories where migrants figure prominently in both. The results yield new insight on MNE decision-making - standard fare for IB research - and new insight on broader societal issues such as institutional change and discrimination - anything but standard.

The special issue article by Kautto (2019) includes illustrative anecdotes, but the primary contribution is theoretical. She is interested in how migrants are perceived by fellow native-born residents. Are they role models to be celebrated or renegades to be sanctioned? The answer matters. We know that migrants are more likely to become entrepreneurs.
A more positive assessment locally means for Kautto that locals are more likely to imitate their entrepreneurial example. Home-country governments should take note. Policies directly promoting entrepreneurship are not always successful. Kautto suggests that policies promoting migrants abroad also promote entrepreneurship back home via this imitation process. "Pro-migrant" policies thus help break a new pathway for promoting private sector, small business, entrepreneur-led economic development. There are specific policy tools associated with Kautto's reasoning. Economic development professionals and their clients will benefit from reviewing them closely.

The special issue article by Christensen et al. (2019) is also primarily theoretical. They develop a nomological net for migrants. For readers who have less familiarity with this exercise, a nomological net represents concepts for study, their empirically observable manifestations, and connections between the concepts and manifestations. The idea is to gain insight on regularized relationships - the nomology or "laws"- among and between the concepts and manifestations. Here, the migrant concepts and manifestations are meant to yield insight on "laws" of migrant entrepreneurship.

Their nomology does not assume that all migrants arrive in a host country voluntarily. Some are refugees from violence while others might be compelled to move because of other outside pressures related to family or culture. Relocation volition matters for how migrants make sense of their host country. Prospective migrant tenure abroad also matters. Some expect to stay forever. Others expect to stay only for a season, a year, a business cycle. These two variables affect migrant propensity to accrue capital, whether that be physical like a truck to haul goods or social like a lending relationship with a local banker. Refugees expecting to stay in the host country for a few months while political violence back home resolves itself, have few incentives to accrue either types of capital. But without that capital, they are also less likely to start a new venture. At the end of this exercise, the nomological net yields quite practical insights. Migrants differ in their entrepreneurial inclination depending on conditions of their arrival and their expected length of stay in host countries. These differences matter for host-country stakeholders depending on migrants to become entrepreneurs. Some are more likely to disappoint. 
The eighth and final article in the special issue is by Poliakova, Riddle, and Cummings (2019). It is a case study about FDI, but this time the story is about how to attract inward FDI. It is about how migrant-run businesses located abroad might be enticed to expand or re-locate in the homeland. It is about how the government in the homeland might create a program to offer extrinsic incentives like tax breaks to entice those migrant-run businesses. And it is about how that homeland investment development agency (IDA) might work in a public-private partnership (PPP) with a non-governmental migrant organization to offer additional intrinsic incentives playing on the ancestral heartstrings of their owners.

Their case study about the Succeed in Ireland initiative has all of that and more. The IDA of Ireland negotiates an agreement with a migrantoriented non-governmental organization called ConnectIreland to help identify and attract businesses run by Irish migrants back to the Emerald Isle. The idea is that ConnectIreland will be better at finding these businesses and can appeal to the non-economic social incentives - heartstrings - of their migrant executives. The IDA can continue to offer their standard package of financial incentives, but those incentives will be more enticing for migrant executives also getting the pitch from ConnectIreland.

The case study provides a novel context for studying PPPs involving a potential mismatch in incentives among the two partners often targeting the same companies. The IDA and migrant organizational partner soon experience conflicts over which one actually recruited a new migrant-run business from overseas. IDA officials thought they were enticing the companies to invest in Ireland with standard financial incentives. ConnectIreland leaders thought they were attracting many of the same companies and deserved a commission from the IDA for that service. Both partners suspected the other of shirking. Poliakova et al. (2019) explain the PPP motivations, structures, mismatches in incentives, and eventual breakdown. Together, the case study contributes valuable insights grounded in principal-agent, transaction costs, and institutional theories, all in the context of current MMP issues. Their case study of the Succeed in Ireland initiative can become the basis for grounded theory and follow-on empirical research using broad-sample statistical methods.

\section{CONCLUDING THOUGHTS ON THE SPECIAL ISSUE ARTICLES}

Where an individual lives is still the most important predictor of her income (Milanovic, 2013). If location matters more than other factors like education, parental education, or gender then people looking for a better life will continue to move. In the 2020s, the population of Diasporia is likely to increase absolutely and as a percentage of the total world population. That prospect means more people on the move. It also means more money flowing back to where they were, whether that be in the form of remittances back to homecountry households or FDI from migrant-run businesses, or portfolio flows from migrant-run investment firms. It also means more knowledge moving within and between firms. More migrants with more money and more knowledge can benefit adroit firms and governments. But they can also create tensions with native-born residents who see migrants as rivals for jobs and drains on public resources. As Mudambi (2018) has noted in this journal, rising migrant importance and native-born anxiety yield a social mixture with explosive properties.

The articles in this special issue contributed insights on how these flows may vary due to, say, home-country diaspora engagement institution type (Cummings \& Gamlen, 2019) immigration system points (Chand \& Tung, 2019) or PPP design (Poliakova et al., 2019) enticing these flows, or broader social attitudes toward the migrant executives directing these flows (Kautto, 2019). They contributed insights on how these flows may vary due to host-country factors like migrant knowledge (Kunczer et al., 2019) or the conditions of migrant arrival (Christensen et al., 2019), maybe even the MNE stewardship (Reade et al., 2019), or the strength of professional purpose (Emmanuel et al., 2019). By studying these home- and host-country factors, we gain insight on current MMP issues and their implications for IB executives and investors looking to benefit from migrant movements, migrant money, and migrant knowledge.

But perhaps there are more important movements afoot when migrants travel. They also transfer norms, sentiments. When MNEs move into fragile states and employ refugees scarred by war they demonstrate how firms can contribute to broader economic development and social security (Reade et al., 2019). When physicians choose to 
remain and minister to the health needs of their fellow citizens rather than leave for a larger paycheck, they demonstrate a civic virtue that others may imitate (Emmanuel et al., 2019). By contrast, when a diaspora engagement institution serves no purpose other than to employ the relatives of politicians in power, it alienates migrants and their willingness to "give back" to the homeland (Cummings \& Gamlen, 2019).

The actions of MNEs, politicians, and leading citizens influence the dissemination of ideas and sentiments that can encourage or discourage migrant support for institutions critical to nationbuilding, whether those institutions be in home or host countries. Perhaps that proposition merits more near-term IB research attention. We could analyze the social impact of MNE FDI on a country hosting a large migrant diaspora with changes in related social attitudes in the migrant home country. We could break those analyses down by the composition of that diaspora - voluntarily or involuntary in origin, temporary or long-standing in tenure, more male or female in gender, younger or older in age, documented or undocumented in legal status. Follow-on research in these directions and others will break new paths connecting current MMP issues to IB research.

\section{ACKNOWLEDGEMENTS}

This special issue grew out of a day-long symposium held on June 25, 2018 at the University of St. Thomas' Opus School of Business located in Minneapolis, Minnesota. We thank the several sponsors of that symposium: Academy of International Business, Journal of International Business Policy (JIBP), George

\section{REFERENCES}

Ács, Z., \& Szerb, L. 2007. Entrepreneurship, economic growth and public policy. Small Business Economics, 28(2-3): 109122.

Aubet, M. 2013. Commerce and colonialization in the ancient near east. Cambridge: Cambridge University Press.

Barnard, H. 2019. From the editor: The social side of international business policy-mapping social entrepreneurship in South Africa. International Business Policy, 2(1): 1-8.

Barnard, H., \& Pendock, C. 2013. To share or not to share: The role of affect in knowledge sharing by individuals in a diaspora. Journal of International Management, 19(1): 47-65.

Bartlett, C., \& Ghoshal, S. 1989. Managing across borders: The transnational solution. Boston, MA: Harvard Business School.

Bashford, A., \& McAdam, J. 2014. The right to asylum: Britain's 1905 alien's act and the evolution of refugee law. Law and History Review, 32(2): 309-350.

Beine, M., Docquier, F., \& Özden, Ç. 2011. Diasporas. Journal of Development Economics, 95(1): 30-41.
Washington University's Center for International Business Education and Research, University of Pretoria's Gordon Institute of Business Science, University of St. Thomas' Opus College of Business, and the University of Minnesota's Carlson School of Management. We also thank Stefanie Lenway, Liesl Riddle, and Sri Zaheer for their support and assistance in organizing the symposium. The symposium benefitted from invited presentations and commentary from Daniel Ayala, Mary Yoko Brannen, Adam Chilton, Prithwiraj Choudhury, Michael Cummings, Alan Gamlen, Gerardo Guerrero Gomez, Lee Sorensen, and Niel Willardson. We thank Sarianna Lundan and Ari Van Assche for the opportunity to edit JIBP's inaugural special issue. We thank Anne Hoekman for keeping the editorial review and publication process moving apace so smoothly and quickly. Paul M. Vaaler thanks the J. William Fulbright Scholarship Board and the US State Department's Bureau of Educational and Cultural Affairs for a Fulbright Scholarship to South Africa supporting this research.

We are indebted to several reviewers who gave us their time and thoughtful assessments over the past 18 months: Joao Albino-Pimentel, George Balabanis, Jean-Luc Bédard, Daniela Bolzani, Jennifer Brinkerhoff, Marcelo Cano-Kollmann, Henry Chung, Anda David, Kirk Doran, Jing-Lin Duanmu, Driss Habti, Sibylle Heilbrunn, Bernard Hoekman, Barclay James, Sona Kalantaryn, Sari Kerr, Ted Khoury, Besnik A. Krasniqi, Vikas Kumar, Francesco Lissoni, Joel Malen, Candace Martinez, Debmalya Mukherjee, Samuele Murtinu, Thomas Niedomysl, Jennifer Oetzel, Sultan Orazbayev, Pythagoras Petrato, Dragos Radu, Rajeev Sawant, Christian Sellar, Kathleen Sexsmith, Wolfgang Sofka, Marie M. Stack, Siri Terjesen, and Nick Williams.

Booth, D., Calabrese, L., \& Golooba-Mutebi, F. 2018. Kickstarting economic transformation in Rwanda: Four policy lessons and their implications. Briefing Paper (June), Overseas Development Institute, London, UK. https://set.odi.org/wpcontent/ uploads/2018/06/SET-Briefing_Kickstarting-ET-in-Rwanda_ Final.pdf. Accessed 15 October 2019.

Buckley, P., \& Casson, M. 1976. The future of the multinational enterprise. London: MacMillan.

Chami, R., Ekkehard, E., Fullenkamp, C., \& Oeking, A. 2018. Is there a remittance trap? Finance \& Development, 55(3): 44-47.

Chand, M., \& Tung, R. 2019. Skilled immigration to fill talent gaps: A comparison of the immigration policies of the United States, Canada, and Australia. Journal of International Business Policy. https://doi.org/10.1057/s42214-019-00039-4.

Chandler, A. 1962. Strategy and structure: Chapters in the history of the industrial enterprise. Cambridge, MA: MIT Press.

Christensen, L., Newman, A., Herrick, H., \& Godfrey, P. 2019. Separate but not equal: Toward a nomological net for 
migrants and migrant entrepreneurship. Journal of International Business Policy. https://doi.org/10.1057/s42214-01900041-w.

Clegg, J. 2019. From the editor: International business policy: What it is, and what it is not. Journal of International Business Policy, 2(2): 111-118.

Clemens, M., Lewis, E., \& Postel, H. 2018. Immigration restrictions as active labor market policy: Evidence from the Mexican bracero exclusion. American Economic Review, 108(6): 1468-1487.

CNBC. 2019. Apple CEO Tim Cook calls on the senate to pass immigration reform. https://www.cnbc.com/2019/10/17/ apple-ceo-tim-cook-calls-on-senate-to-pass-immigrationreform.html. Accessed 17 October 2019.

Cohen, R. 2008. Global diasporas: An introduction (2nd ed.). London: Routledge.

Cummings, M., Deeds, D., \& Vaaler, P. 2019. Migrant tenure abroad and the differential impact of remittances for entrepreneurship in developing countries. Working paper, University of Minnesota: Minneapolis, MN. https://papers. ssrn.com/sol3/papers.cfm?abstract_id=3460442.

Cummings, M., \& Gamlen, A. 2019. Diaspora engagement institutions and venture investment activity in developing countries. Journal of International Business Policy. https://doi. org/10.1057/s42214-019-00035-8.

Daily Nation. 2019. Kenya, Somalia take first step to normalise relations. September 25. https://allafrica.com/stories/ 201909260111.html. Accessed 15 October 2019.

Docquier, F., \& Marfouk, A. 2006. International migration by education attainment in 1990-2000. In C. Orden \& M. Schiff (Eds), International migration, remittances and the brain drain. Washington, DC: World Bank.

Docquier, F., \& Rapaport, H. 2012. Globalization, brain drain, and development. Journal of Economic Literature, 50(3): 681730.

Drori, I., Honig, B., \& Wright, M. 2009. Transnational entrepreneurship: An emergent field of study. Entrepreneurship Theory and Practice, 33(5): 1001-1022.

Dunning, J. 1977/1976. Trade, location of economic activity and MNE: A search for an eclectic approach. In B. Ohlin, P. Hesselborn, \& P. Wijkman (Eds), The International Allocation of Economic Activity (Proceedings of a Nobel Symposium: Stockholm, Sweden): 395-418. London: Palgrave Macmillan.

Emmanuel, N., Elo, M., \& Piekkari, R. 2019. Human stickiness as counterforce to brain drain: Purpose-driven behavior among Tanzanian medical doctors and implications for policy. Journal of International Business Policy. https://doi.org/10.1057/ s42214-019-00036-7.

Gamlen, A. 2019. Human geopolitics: States, emigrants, and the rise of diaspora institutions. Oxford: Oxford University Press.

Gamlen, A., Cummings, M., \& Vaaler, P. 2019. Explaining the rise of diaspora institutions. Journal of Ethnic and Migration Studies, 45(4): 492-516.

Hernandez, E. 2014. Finding a home away from home: Effects of immigrants on firms' foreign location choice and performance. Administrative Science Quarterly, 59(1): 73-108.

Hymer, S. 1970/1960. The international operations of national firms: A study of direct foreign investment. Cambridge, MA: MIT Press.

IOM. 2018. World migration report: International Organization for Migration. Geneva: United Nations. https://publications.iom. int/system/files/pdf/wmr_2018_en.pdf. Accessed 15 October 2019.

Johnson, B. 2016. Boris Johnson's speech on the EU referendum: full text https://www.conservativehome.com/parliament/ 2016/05/boris-johnsons-speech-on-the-eu-referendum-fulltext.html. Accessed 15 October 2019.

Johnson, P. 1987. A history of the Jews. New York: Harper \& Row. Kautto, D. 2019. Social influences in cross-border entrepreneurial migration policy. Journal of International Business Policy. https://doi.org/10.1057/s42214-019-00040-x.
Kogut, B., \& Singh, H. 1988. The affect of national culture on the choice of entry mode. Journal of International Business Studies, 19(3): 411-432.

Kogut, B., \& Zander, U. 1993. Knowledge of the firm and the evolutionary theory of the multinational corporation. Journal of International Business Studies, 24(4): 625-645.

Kolde, E., \& Hill, R. 1967. Conceptual and normative aspects of international management. Academy of Management Journal, 10(2): 119-128.

Kunczer, V., Lindner, T., \& Puck, J. 2019. Benefitting from immigration: The value of immigrants' country knowledge for firm internationalization. Journal of International Business Policy. https://doi.org/10.1057/s42214-019-00034-9.

Leblang, D. 2010. Familiarity breeds investment: Diaspora networks and international investment. American Political Science Review, 104(3): 584-600.

Lenin, V. 1999/1916. Imperialism: The highest form of capitalism. Chippendale, Australia: Resistance Books.

Lewin, A., Massini, S., \& Peeters, C. 2009. Why are companies offshoring innovation? The emerging global race for talent. Journal of International Business Studies, 40(6): 901-925.

Lorenzen, M., \& Mudambi, R. 2013. Bollywood and Bangalore in the global economy. Journal of Economic Geography, 13: 501-534.

Madhavan, R., \& Iriyama, A. 2009. Understanding global flows of venture capital: Human networks as the "carrier wave" of globalization. Journal of International Business Studies, 40(8): 1241-1259.

Martinez, C., Cummings, M., \& Vaaler, P. 2015. Economic informality and the venture investment impact of migrant remittances to developing countries. Journal of Business Venturing, 30: 526-545.

Meouloud, T., Mudambi, R., \& Hill, T. 2019. The metropolitan effect: Colonial influence on the internationalization of francophone African firms. Management and Organization Review, 15(1): 31-53.

Meyer, J. 2010. World society, institutional theories, and the actor. Annual Review of Sociology, 36: 1-20.

Milanovic, B. 2013. Global income inequality in numbers: In history and now. Global Policy, 4(2): 198-208.

Mudambi, R. 2018. Knowledge-intensive intangibles, spatial transaction costs and the rise of populism. Journal of International Business Policy, 1(1-2): 44-52.

Murrow, J. 1988. International entrepreneurship: A new growth opportunity. New Management, 3: 5961.

New York Times. 2019. Trump hits the wall: And what's all that sniffling about? January 9. https://www.nytimes.com/2019/ 01/09/opinion/trump-border-speech.html. Accessed 15 October 2019

Oviatt, B., \& McDougall, P. 1994. Toward a theory of international new ventures. Journal of International Business Studies, 25(1): 45-64.

Özden, Ç., Parsons, C., Schiff, M., \& Walmsley, T. 2011. Where on Earth is everybody? The evolution of global bilateral migration 1960-2000. The World Bank Economic Review, 25(1): 12-56.

Poliakova, E., Riddle, L., \& Cummings, M. 2019. Public-private partnerships and diaspora investment promotion: The Succeed in Ireland initiative. Journal of International Business Policy. https://doi.org/10.1057/s42214-019-00044-7.

Portes, A., Haller, W., \& Guarnizo, L. 2002. Transnational entrepreneurs: An alternative form of immigrant economic adaptation. American Sociology Review, 67(2): 278-298.

Reade, C., Oetzel, J., \& McKenna, M. 2019. Unmanaged migration and the role of MNEs in reducing push factors and promoting peace: A strategic HRM perspective. Journal of International Business Policy. https://doi.org/10.1057/s42214019-00043-8.

Reuters. 2016. 'Bachelor ban' in Qatar tests relations with migrant workers. May 17. https://www.reuters.com/article/ 
us-qatar-labour-bachelors-idUSKCN0Y81H4. Accessed 15 October 2019.

Rogers, E. 1962. Diffusion of innovations. New York: Free Press. Rudolph, H. 2010. The new gastarbeiter system in Germany. Journal of Ethnic and Migration Studies, 22(2): 287-300.

Ryan, R., \& Deci, E. 2000. Intrinsic and extrinsic motivations: Classic definitions and new directions. Contemporary Educational Psychology, 25(1): 54-67.

Saxenian, A. 2005. From brain drain to brain circulation: Transnational communities and regional upgrading in India and China. Studies in Comparative International Development, 40(2): 35-61.

Saxenian, A., \& Hsu, J. 2001. The Silicon Valley- Hsinchu connection: Technical communities and industrial upgrading. Industrial and Corporate Change, 10(4): 893-920.

Schotter, A., Mudambi, R., Doz, Y., \& Gaur, A. 2017. Boundary spanning in global organizations. Journal of Management Studies, 54(4): 403-421.

Schuler, R., Jackson, S., \& Tarique, I. 2011. Global talent management and global talent challenges: Strategic opportunities for IHRM. Journal of World Business, 46(4): 506-516.

Shukla, P., \& Cantwell, J. 2018. Migrants and multinational firms: The role of institutional affinity and connectedness in FDI. Journal of World Business, 53(6): 835-849.

Teece, D. 1977. Technology transfer by multinational firms: The resource cost of transferring know-how. The Economic Journal, 87(346): 161-242.

Teece, D. 1986. Transactions cost economics and the multinational enterprise: An assessment. Journal of Economic Behavior \& Organization, 7(1): 21-45.

Tichenor, D. 2002. Dividing lines: The politics of immigration control in America. Princeton, NJ: Princeton University Press.

UNHCR. 2019. 2018 Global trends: Forced displacement in 2018. Geneva: United Nations High Commission for Refugees. https://www.unhcr.org/5d08d7ee7.pdf. Accessed 15 October 2019.

Vaaler, P. 2011. Immigrant remittances and the venture investment environment of developing countries. Journal of International Business Studies, 42(9): 1121-1149.

Vaaler, P. 2013. Diaspora concentration and the venture investment impact of remittances. Journal of International Management, 19: 26-46.

Van Assche, A. 2018. From the editor: Steering a policy turn in international business-opportunities and challenges. Journal of International Business Policy, 1(3-4): 117-127.

Williams, A. 2007. Listen to me, learn with me: International migration and knowledge transfer. British Journal of Industrial Relations, 45(2): 361-382.

Wilson, K., \& Portes, A. 1980. Immigrant enclaves: An analysis of the labor market experiences of Cubans in Miami. American Journal of Sociology, 86: 295-319.

World Bank. 2019. Record high remittances sent globally in 2018. Washington, DC: World Bank. https://www.worldbank.org/ en/news/press-release/2019/04/08/record-high-remittancessent-globally-in-2018. Accessed 15 October 2019.

\section{ABOUT THE AUTHORS}

Helena Barnard is a professor and the Director of Doctoral Programs at the University of Pretoria's Gordon Institute of Business Science. She received her PhD in management from Rutgers University. She studies how knowledge moves between more and less developed countries and is especially interested in organizational and individual transfer mechanisms such as multinational enterprises, internet-based firms, scientific collaborations, doctoral training, and diasporas.

David Deeds is a professor and the Schulze Endowed Chair in Entrepreneurship at the University of St. Thomas' Opus College of Business. He received his PhD in strategic management and entrepreneurship from the University of Washington. He studies new venture growth. He is especially interested in growth and adaptation processes related to technological discontinuities, strategic alliances, and migration.

Ram Mudambi is a professor and the Frank M. Speakman Professor of Strategy and Perelman Senior Research Fellow at Temple University's Fox School of Business. He received his PhD in economics from Cornell University. He studies technology and innovation management and is especially interested in the geography of innovation in multinational enterprises, entrepreneurial firms, and diasporas.

Paul M. Vaaler is a professor and the John and Bruce Mooty Chair in Law and Business at the University of Minnesota's Law School and Carlson School of Management. He received his $\mathrm{PhD}$ in strategic management from the University of Minnesota. He studies international business and is especially interested in how foreign investing firms and individuals respond to policy reforms and migration in developing countries.

Publisher's Note Springer Nature remains neutral with regard to jurisdictional claims in published maps and institutional affiliations. 